\title{
Analysis of the Effect of E-Service Quality on Hospital Customer Satisfaction (Study of E-Service Quality Hospitals in West Java, Indonesia)
}

\author{
Anggono Raras Tirto Sakti ${ }^{1, *}$
}

\author{
${ }^{l}$ STIE Indonesia Membangun \\ ${ }^{*}$ Corresponding author.Email: anggono72018@gmail.com
}

\begin{abstract}
Research on the analysis of e-service quality (ESQ), on customer satisfaction hospitals in West Java has been conducted at Advent, Immanuel, Santo Yusuf, and RSUD Bandung City Hospital. This research was conducted on 200 respondents. The data processing method used in this study was SmartPLS 3. The results of this study proved that empirically the description of the latent variables of E-Service Quality (ESQ), Customer Satisfaction, and the Image of Hospitals in Hospitals in West Java were valid. E-Service Quality (ESQ) had a moderate effect on customer satisfaction. Increased ESQ will lead to moderate increased hospitals customer satisfaction. in West Java. The increase in ESQ will cause an increase in the hospital's image as well. Customer satisfaction had a strong influence on the image of hospitals in West Java. Increased customer satisfaction will cause a higher increase in hospital image. E-Service Quality (ESQ) had a strong influence on the image of hospitals in West Java, both partially and simultaneously.
\end{abstract}

Keywords: e-service quality, customer satisfaction, hospital, Bandung.

\section{INTRODUCTION}

The variables used in this study were latent variables consisted of e-service quality, and customer satisfaction. E-service quality has indicators of Efficiency, Responsiveness, Compensation, Contact [1]. In the customer satisfaction variable, there are two indicators namely Expectation and Perception [2, 3].

This study was conducted at the Type B Hospital, which is able to provide medical services and other services according to applicable regulations. Examples of medical services provided are emergency services to dental and oral specialist medical services [4].

Table 1 illustrates the conditions of hospitals in West Java, namely the number and owners of hospitals, hospital classes, and the number of hospitals in West Java. The hospitals in West Java are owned by seven agencies, namely the government, hospitals, military/police, vertical, private hospitals, special government, and hospital classes, and the number of state-owned hospitals in Bandung is shown in Table 1.

Table 1. Total Hospitals in West Java

\begin{tabular}{|l|l|l|}
\hline No & \multicolumn{1}{|c|}{ Owners } & \multicolumn{1}{c|}{ Total } \\
\hline 1 & Government Hospital & 70 Hospitals \\
\hline 2 & RSUD & 44 Hospitals \\
\hline 3 & TNI/POLRI Hospital & 13 Hospitals \\
\hline 4 & Vertical Hospital & 5 Hospitals \\
\hline 5 & Private hospital & 258 Hospitals \\
\hline 6 & Special Government Hospital & 5 Hospitals \\
\hline 7 & BUMN Hospital & 3 Hospitals \\
\hline
\end{tabular}

The number of hospitals in West Java by class are as follows: class A has 9 hospitals, class B, 54 hospitals, class C has 160 hospitals, and class D has 58 hospitals (see Table 2). 
Table 2. Total Hospitals by class in Wsst Java.

\begin{tabular}{|l|l|l|}
\hline \multicolumn{1}{|c|}{ No } & \multicolumn{1}{|c|}{ Class } & \multicolumn{1}{c|}{ Total } \\
\hline 1 & Class A & 9 Hospitals \\
\hline 2 & Class B & 54 Hospitals \\
\hline 3 & Class C & 160 Hospitals \\
\hline 4 & Class D & 58 Hospitals \\
\hline
\end{tabular}

\section{METHODS}

\subsection{Model of Study}

Data processing in this study used SmartPLS 3, so that the research methods used in the research were descriptive and verification research [6,7]. Descriptive methods are used to assess the outer model, and verification research is used to measure the inner model. The variables and indicators study are shown in Table 3.

Table 3. Variables and Indicator Study.

\begin{tabular}{|l|l|}
\hline \multicolumn{1}{|c|}{ Variables } & \multicolumn{1}{|c|}{ Indicators } \\
\hline \multirow{4}{*}{ E-Service quality } & Efficiency \\
\cline { 2 - 2 } & Responsiveness \\
\cline { 2 - 2 } & Compensation \\
\cline { 2 - 2 } & Contact, \\
\hline \multirow{4}{*}{$\begin{array}{l}\text { Customer } \\
\text { satisfaction }\end{array}$} & Expectation \\
\cline { 2 - 2 } & Perception \\
\hline
\end{tabular}

\subsection{Hypotheses}

The hypotheses in this study are: E-Service Quality: H0.1: $\pi 1=0.5$ : E-Service Quality which includes efficiency, responsiveness, compensation, and hospital contact in West Java that is not well owned. H1.1: $\pi 1>$ 0.5: E-Service Quality which includes efficiency, responsiveness, compensation, and hospital contact in West Java has been well owned.

Customer satisfaction [8]: H0,2: $\pi 2=0.5$ : Customers are not satisfied with the services provided by hospitals in West Java. H1.2: $\pi 2>0.5$ : Customers are satisfied with the services provided by the Hospital in West Java.

Effect of E-Service Quality on customer satisfaction of hospitals in West Java. H0,4: $\gamma 1=0$ : There is no effect of E-Service Quality on Hospital Customer Satisfaction in West Java. H1,4: $\gamma 1 \neq 0$ : There is an influence of E-Service Quality on Hospital Customer Satisfaction in West Java.

\section{RESULT AND DISCUSSION}

\subsection{Characteritic Respondents}

Characteristics of respondents in this study can be divided into four, namely gender, education, occupation, and age. Gender consists of 43 percent Female and 57 percent male. Education consists of 35 percent of high school-D3, 30 percent $\mathrm{S} 1$, and 35 percent S2-S3. Occupations consisted of 33 percent private, 22 percent students, 19 percent government, and 26 percent others, see Table 4.

Table 4. Characteritic Respondents

\begin{tabular}{|l|l|}
\hline \multicolumn{1}{|c|}{ Variables } & \multicolumn{1}{c|}{ Indicators } \\
\hline \multirow{4}{*}{ Gender } & Male (43\%) \\
\cline { 2 - 2 } & Female (57\%) \\
\hline \multirow{5}{*}{ Education } & Hgh School + \\
\cline { 2 - 2 } & Diploma 3 (35\%) \\
\cline { 2 - 2 } & Bachelor (30\%) \\
\cline { 2 - 2 } & Post Graduate (35\%) \\
\hline & Privat (33\%) \\
\cline { 2 - 2 } & Student (22\%), \\
& Government (19\%) \\
\cline { 2 - 2 } & Others (26\%) \\
\hline
\end{tabular}

\subsection{Descriptive Test}

Validity test outer loadings on variable independent obtained efficiency value of 0.0774 , responsiveness amounted to 0.842 , compensation amounted to 0.744 , and contact amounted to 0.664, where efficiency, responsiveness, compensation, and contact are greater than the cut-off value of $0.6-0.7$, so all four indicators are valid. Variable dependent shows the results of the expectation test of 0.911 and perception of 0.906 and both indicators are greater than 0.6-0.7 (cut off values), then expectation and perception are valid, as shown in Table 5 .

Table 5. Validity Test Outer Loadings.

\begin{tabular}{|l|l|l|l|l|l|}
\hline No & \multicolumn{1}{|c|}{ Indicators } & ESQ & $\begin{array}{c}\text { Customer } \\
\text { Satisfactio }\end{array}$ & $\begin{array}{c}\text { Cut Off } \\
\text { Value }\end{array}$ & Remarks \\
\hline 1 & Efficiency & 0.774 & & $>(0.6-0.7)$ & Valid \\
\hline 2 & Responsiveness & 0.842 & & $>(0.6-0.7)$ & Valid \\
\hline 3 & Compensation & 0.744 & & $>(0.6-0.7)$ & Valid \\
\hline 4 & Contact & 0.664 & & $>(0.6-0.7)$ & Valid \\
\hline 5 & Expectation & & 0.911 & $>(0.6-0.7)$ & Valid \\
\hline 6 & Perception & & 0.906 & $>(0.6-0.7)$ & Valid \\
\hline
\end{tabular}

Source:[9].

In this discriminant validity test, the results consist of cross loading. At cross loading, the loading factor value can be seen from the latent variable E-Service Quality (ESQ): efficiency $=0.774$, responsiveness = 0.842 . compensation $=0.744$, and contact $=0.664$. While the loading factor value for latent variables Customer Satisfaction: expectation $=0.911$, and perception $=0.906$. All factor loading values are greater than the standard value, which is $0.6-0.7$. Thus, from the discriminant validity test all indicator values are valid (see Table 6).

Table 6. Discriminant Validity Test.

\begin{tabular}{|l|c|c|l|}
\hline $\begin{array}{c}\text { Variable } \\
\text { Latent }\end{array}$ & $\begin{array}{c}\text { Cross } \\
\text { Loading }\end{array}$ & $\begin{array}{c}\text { Cut Off } \\
\text { Value }\end{array}$ & Remarks \\
\hline ESQ & $>(0.6-0.7)$ & Valid \\
\hline Efficiency & 0.774 & $>(0.6-0.7)$ & Valid \\
\hline Responsiveness & 0.842 & $>(0.6-0.7)$ & Valid \\
\hline Compensation & 0.744 & $>(0.6-0.7)$ & Valid \\
\hline Contact & 0.664 & $>(0.6-0.7)$ & Valid \\
\hline Cuatomer Satisfaction :
\end{tabular}




\begin{tabular}{|l|l|l|l|}
\hline Perception & 0.906 & $>(0.6-0.7)$ & Valid \\
Source: $[10]$.
\end{tabular}

The construct validity test based on the results of data processing with the SmartPLS 3 application, it was obtained the Average Variance Extracted (AVE) latent variable E-service quality of 0.578 and customer satisfaction of 0.826 . The results of this measurement are compared with the required cut-off value $>0.5$, so that these two latent variables are valid (see Table 7).

Table 7. Constructs Validity Test.

\begin{tabular}{|l|l|l|l|l|}
\hline No & Latent Variable & Result & $\begin{array}{c}\text { Cut Off } \\
\text { Value }\end{array}$ & Remarks \\
\hline 1 & E-service quality & 0.575 & $>0.5$ & Valid \\
\hline 2 & $\begin{array}{l}\text { Customer } \\
\text { Satisfaction }\end{array}$ & 0.826 & $>0.5$ & Valid \\
\hline
\end{tabular}

From Tables 5, 6, and 7 it is proven that $\mathrm{H} 0,1: \pi 1=$ 0.5: E-Service Quality which includes efficiency, responsiveness, compensation, and hospital contact in West Java has not been well owned, so the hypothesis is rejected. H1.1: $\pi 1>0.5$ : E-Service Quality which includes efficiency, responsiveness, compensation, and hospital contact in West Java has been well owned, so the hypothesis is accepted.

H0,2: $\pi 2=0.5$ : The customer is not satisfied with the services provided by the hospital in West Java, so the hypothesis is rejected. H1.2: $\pi 2>0.5$ : Cus-tomers are satisfied with the services provided by the hospital in West Java, so the hypothesis is accepted.

Statistical Collinearity Test based on the results of data processing was obtained in Statistical Collinearity (VIF), in which inner VIF value for customer satisfaction is 1,000 , and if the measurement results are compared with the required standard of $<0.5$ then it means that the data is free from multi collinearity (see Table 8).

Table 8. Collinearity Statistic Test (VIF)

\begin{tabular}{|l|l|l|l|l|}
\hline No & \multicolumn{1}{|c|}{$\begin{array}{c}\text { Variabel } \\
\text { Latent }\end{array}$} & Result & $\begin{array}{c}\text { Cut Off } \\
\text { Value }\end{array}$ & \multicolumn{1}{|c|}{ Remarks } \\
\hline 1 & $\begin{array}{l}\text { E-quality } \\
\text { service }\end{array}$ & - & - & - \\
\hline 2 & $\begin{array}{l}\text { Customer } \\
\text { satisfaction }\end{array}$ & 1.000 & $<0.5$ & $\begin{array}{l}\text { Not-Multi } \\
\text { collenearity }\end{array}$ \\
\hline
\end{tabular}

\subsection{Verificative Test}

$\mathrm{R}$ Square Test is carried out to determine the effect on latent variables customer satisfaction which scored 35 percent categorized as moderate (see Table 9).

Table 9. R Square Test

\begin{tabular}{|l|l|l|l|l|l|}
\hline No & \multicolumn{1}{|c|}{$\begin{array}{c}\text { Latent } \\
\text { Variable }\end{array}$} & \multirow{2}{*}{ Result } & \multicolumn{2}{|c|}{$\begin{array}{c}\text { Cut Off } \\
\text { value }\end{array}$} & \multicolumn{1}{|c|}{ Remarks } \\
\hline \multirow{2}{*}{1} & \multirow{2}{*}{$\begin{array}{l}\text { Customer } \\
\text { satisfaction }\end{array}$} & \multirow{2}{*}{0.350} & 0.67 & 0.75 & Strong \\
\cline { 4 - 6 } & & 0.33 & 0.50 & Moderat \\
\cline { 3 - 6 } & & 0.19 & 0.25 & Weak \\
\hline
\end{tabular}

Source: [9].
The Path Coefficients Test shows the magnitude of the influence of the latent e-service quality (ESQ) variable on the latent variable Customer satisfaction which valued 0 percent. It can be seen in the calculated Boost Path Coefficients, in $\mathrm{P}$ Values, that a value of 0.000 is obtained, which means the latent variable has a significant effect (see Table 10).

Table 10. Path Coefficients Test

\begin{tabular}{|l|l|l|l|l|}
\hline No & Latent Variable & \multicolumn{1}{|c|}{$\begin{array}{c}\text { P } \\
\text { Value }\end{array}$} & $\begin{array}{c}\text { Cut Off } \\
\text { value }\end{array}$ & Remarks \\
\hline 1 & $\begin{array}{l}\text { ESQ } \\
\text { Cust.Satisfaction }\end{array}$ & 0.000 & $<0.05$ & $\begin{array}{l}\text { Significa } \\
\mathrm{nt}\end{array}$ \\
\hline
\end{tabular}

From Tables 8, 9, and 10 it is proven that: The effect of e-service quality on customer satisfaction of hospitals in West Java with H0,4: $\gamma 1=0$ : means that there is no effect of e-service quality on hospital customer satisfaction in West Java, so the hypothesis is rejected. While $\mathrm{H} 1,4: \gamma 1 \neq 0$ means that there is an effect of eservice quality on hospital customer satisfaction in West Java, so the hypothesis is accepted.

\section{CONCLUSION}

From the results of the study, it can be stated that Eservice quality and customer satisfaction were mutually supportive variables. E-service quality had a significant effect on customer satisfaction. The results of this study then can be used to develop next studies. It is suggested for further study to examine endogenous latent variables that are influenced by E-Service Quality variables.

\section{REFERENCES}

[1] S. Rose, M. Clark, P. Samouel, and N. Hair, "Online customer experience in e-retailing: an empirical model of antecedents and outcomes," J. of Retailing, vol. 88, no. 2, pp. 308-322, 2012.

[2] Kotler, P., \& Keller, K. L. (2009). Marketing Management 13th Edition. New Jersey: Prentince Hall International.

[3] Sugiyono, Metode Penelitian Bisnis. Bandung: Alfabeta, 2012.

[4] Regulation of the Minister of Health of the Republic of Indonesia (Number 56; 2014), Type of Hospital in Indonesia.

[5] Statistik Indonesia, Badan Pusat Statistik (BPS), 2016. [Online]. Available: https://www.bps.go.id/.

[6] Sugiyono, Metode Penelitian Kuantitatif Kualitatif dan $R \& D$. Bandung: Alfabeta, 2009.

[7] K.G. Joreskog and H. Wold, "The ML and PLS techniques for modeling with latent variables historical and comparative aspects," North Holland, vol. 1, pp. 263-270, 1982.

[8] F. Tjiptono and G. Chandra, Service, Quality \& Satisfaction. Yogyakarta: Andi, 2011. 
[9] J.F. Hair, W.C. Black, B.J. Babin, R.E. Anderson, and R.L. Tatham, Multivariate data analysis, new international ed. Harlow: Pearson Education, 2014.
J.F. Hair, W.C. Black, B.J. Babin, R.E. Anderson, and R.L. Tatham, Multivariate data analysis, fifth ed. Harlow: New Jersey: PrenticeHall, Inc., 2011. 